\title{
"Adoption of New Technology in Farm Situation with The Special Reference to Vegetable Cultivation" - A Case Study in Darrang Dist. of Assam.
}

\author{
Dr. Mizanur Rahman \\ Associate. Prof. Dept. of Economics, Kharupetia College, Darrang, Assam. \\ DOI: 10.29322/IJSRP.11.01.2021.p10962 \\ http://dx.doi.org/10.29322/IJSRP.11.01.2021.p10962
}

\begin{abstract}
The special focus on technological change in farm situation: economics of vegetables cultivation in Darrang District of Assam. Darrang is one of the most important district of Assam in respect of technological change of agriculture and situated at attitude of crops growing in the district are paddy, jute, mustard, potato, tomato, vegetables etc. Paddy is the staple food crop of the district. The major field crops grown in Darrang district are cereal, pulses oilseed, jute and the indigenous vegetables are common part of the diet of the cultivators. Most of these vegetables are eaten for their properties. Proper documentation is need for these probable endangered indigenous crop. For the purpose of the present study, a structured questionnaire was prepared and presented the development of the technological inventions. Technological for bio-control of potato tuber moth, rice, weevil and standardization of cultivation of wild edible mushroom and also to identified the short duration wheat varieties or high yield varieties as well as technology for organics vegetable cultivation and to find out of seed village. The total sample of farmers of 200 consisted from the Darrang district of Assam randomly selected. The descriptive survey method employed in this study. It was found that the farmers and vegetable cultivation did not reach any level of significant.
\end{abstract}

Index Terms- Food grains, Production, Productivity, Fertilizer Consumption, Pesticides, Agriculture, Farmer, Technological Change. Agricultural credit, Crops. Vegetable Cultivation.

\section{INTRODUCTION}

A griculture occupies a vital position in the State's economy engaging about 53 percent of the total working force, according to 2001 census. The contribution of the Sector in State Domestic Product (SDP) at constant and current prices are 31.08 percent and at 31.13 percent respectively in 2002-2003. Vegetables play a vital role in the nutritional security of the Indian population and financial economy of the majority of small marginal farmers. In the light of agriculture diversification, vegetables have to play a significant role by providing scope and opportunity for employment generation through export trade and post harvest industry development.

The technological change in agriculture means the application of modern technical know-how to the different phases of production. The basic components of new innovation in the field of agriculture may be considered mechanization or wide-use of farm machinery tools and implements, improving soil and making it most fit for cultivation, soil conservation, new varieties of seeds, chemical fertilizers, irrigation, pest control and other several methods of raising yield and net returns per hectare. The technological changes results in raising the degree of efficiency and self-sufficiency in agriculture and at the same time in the commercialization of agriculture with both high yield per hectare and high productivity per man technological changes have tremendous possibilities for solving the current atrophy in agriculture situation especially in Assam.

\section{NeEd And SignificAnce of the Present Study:}

Development of the economy in any farm is the outcome of human activity. This activity in men envisages three roles as an organizers, worker, farmer as well as cultivators and as a user of good produced, of these, the role of man in organizing the factors of production is very important in this present study. Unless the skills and resources provided by the nature are fully transformed into efficient production units, i.e. at present covers paddy, millets, cabbage, cauliflower, brinjal as well as beet, cucumber,chillies etc. The man's or farmers labour will remain largely unproductive and keeps his levels of consumption very low. The size of the farming community is constituted as small farmers and marginal farmers. Hence, sustainable development must primarily come through small and marginal farmers and this could be achieved in few agricultural technologies is adopted by these farmers along with the rest.

The main focus of the present study, now that there is little scope to bring addition areas under cultivation, the increase in agricultural production in future has to come mainly from increase in productivity. This in turn would depend upon a judicious use as irrigation, fertilizer seeds, and plantprotection. On the one hand, technological advancement in crop science on the other focus in this study.

\section{Objectives Of The Present Study:}

1. To identify the factor that influences the adoption of new agricultural technology by different categories of farmers in the study blocks. 
2. To identify the major factors responsible for not capturing the benefit of non-cereal crops like vegetable by the farmers.

3. To evaluate the impact of adoptions of new agricultural technology on the growth and productivity of agriculture.

4. To find out the constraint to adoption of new technology by different categories of farmers.

5. To study the role of government and-government extension services in motivating the farmers to adopt improved technology of production.

6. To suggest measures for accelerating agricultural development by adopting new technology in the region under study.

\section{Hypotheses of THE PRESENT STUDy:}

1. There are exists level of significant differences for different farmers and demand for non-cereal crops has been increased then the cereal crops.

2. That farm size and income are positively correlated with the adoption of new agricultural technology.

3. The institutional credit for agriculture facilities the adoption process.

4. That adoption of improved agricultural practices depends upon assured irrigation facilities.

5. That fluctuating agricultural prices and underdevelopment market condition of agricultural produces stand on the way of adoption of new agricultural technology.

6. That extension services can play important role in motivating farmers to adopt new technology.

\section{Methodology:}

The proposed study may be precisely stated as, "Vegetable Cultivation in Darrang District of Assam". For this purposes the descriptive research method used. The plan of action has to be drawn up to ensure scientific and objective merits of the study. The geographical area to be covered, the sample to be selected and data collection team to be organized, all such items of plan were clearly drawn out. It was also decided whether survey would be purely cross-sectional study.

\section{SAMPLE:}

A sample is the process of obtaining information about an entire population by examining only a part of it. Sampling may be defined as the selection of some part of an aggregate or totality on the basis of which a judgement or inference about the aggregate or totality is made. In the present study the size of the sample would be randomly selected of 200 consists farm household of 10 villages in 3 development blocks-Dalgaon, Becimari and PubMangaldai of Darrang district in Assam.The total 200 sample of farmers taken from districtDarrang in Assam.

Table: 1

Table showing the Block-wise Distribution of New Agricultural Technology by Different Categories of Farmers N= 200

\begin{tabular}{|c|c|c|c|}
\hline Name of Block & Constant & Standard Error & Coefficient(R) \\
\hline Dalgaon & 3150.42 & 203.08 & 0.310 \\
\hline Becimari & 3011.63 & 221.94 & 0.333 \\
\hline Pub- Mangaldai & 3730.63 & 285.69 & 0.219 \\
\hline Categorised Farmers & \multicolumn{3}{|c|}{ Land Holding } \\
\hline Large Farmers & \multicolumn{3}{|c|}{2 hect. and above (15 Bighas and above) } \\
\hline Medium Farmers & \multicolumn{3}{|c|}{1 to 2 hect. 7 1/2( Bighasto 15 Bighas) } \\
\hline Small Farmers up to & \multicolumn{3}{|c|}{1 hect. (Upto 7 1/2 Bighas) } \\
\hline
\end{tabular}

\section{Source: Agricultural Office Darrang District in Assam}

From the Table No. 1, observed that of the total farmer and land possessed by the farmers of coefficient of correlation are $0.310,0.333$ and 0.219 respectively. Districts- wiser distribution shows that Becimari Block is non-irrigated. The proportion of irrigated land to total land area is very lees amongst large farmers. Furthermore, the average of irrigated land possessed by the farmer 
is just 1-2 acre. Indicating that agricultural land is mainly concentrated among larger landholders. Most farmers cultivate almost their entire cultivable land. However, the proportion of farmers cultivating land during the rabi season and amount of land cultivated increases as the size of the cultivated holding increased.

Table: 2

Improved Varieties of Seeds Supplied to the Cultivators through Seed Agencies- 2009-2010

\begin{tabular}{|l|l|l|}
\hline Seeds & 2009 & $2009-2010$ \\
\hline Wheat & 79,402 & $1,78,137$ \\
\hline Brinjal & 11,359 & 2,000 \\
\hline Rice & 1,275 & 1,532 \\
\hline Berseem & 271 & 42 \\
\hline Tomato & 503 & 5,255 \\
\hline Barley & 267 & 11,000 \\
\hline Jute & 20,900 & 29,028 \\
\hline Potato & 244 & 595 \\
\hline Cauliflower & & 112 \\
\hline
\end{tabular}

Source: Agricultural Office Darrang District in Assam.

Table: 3

Table Showing the Price of Commodity of Darrang District in Assam.

\begin{tabular}{|c|c|c|c|c|}
\hline \multirow[t]{3}{*}{ Name of Crop } & \multicolumn{2}{|c|}{ Early Season } & \multicolumn{2}{|l|}{ Last Season } \\
\hline & Whole Sale & Retail Sale Price & Whole Sale & Retail Sale \\
\hline & Price & & Price & Price \\
\hline Paddy & 1000 & 1200 & 1600 & 1700 \\
\hline Wheat & 700 & 1400 & 1450 & 1750 \\
\hline Jute & 1600 & 1800 & 2100 & 2500 \\
\hline Potato & 500 & 600 & 800 & 850 \\
\hline Tomato & 500 & 600 & 700 & 900 \\
\hline Cabbage & 400 & 700 & 800 & 900 \\
\hline Cauliflower & 500 & 600 & 800 & 1200 \\
\hline Brinjal & 700 & 800 & 950 & 1200 \\
\hline Chilly & 1500 & 1700 & 2600 & 2800 \\
\hline Bean & 1200 & 1490 & 1700 & 1900 \\
\hline Carrot & 1300 & 1500 & 1800 & 1900 \\
\hline Pea & 1100 & 1200 & 600 & 800 \\
\hline Other Veg, & 700 & 1200 & 1500 & 1600 \\
\hline
\end{tabular}

Source: Agricultural Office Darrang District in Assam 
The improved varieties of seed of wheat and cotton used by the farms were almost two and a half times more in 2005-06 over those of 2009-10. The quantities of improved bajra and barley seeds were ten times and four times more respectively during $2009-2010$. In the initial stages, package approach was adopted through the Intensive Agricultural District Programme to stimulate the agricultural production. It was again modified in the form of Intensive area programme which laid emphasis on specific crops.

Table: 4

Table Showing the Amount of Fertilizer for Specific Crop/Bighas (in k.g)

\begin{tabular}{|c|c|c|c|c|c|c|c|c|c|c|}
\hline $\begin{array}{l}\text { Name of } \\
\text { Crop }\end{array}$ & Urea & Potash & $\begin{array}{l}\text { Super } \\
\text { Phosphate }\end{array}$ & DAP & Bipul Dana & $\begin{array}{l}\text { Bio } \\
\text { Power }\end{array}$ & Himusil & Soil & $\begin{array}{l}\text { Org. } \\
\text { Manure }\end{array}$ & $\begin{array}{l}\text { Total } \\
\text { Exp. }\end{array}$ \\
\hline Paddy & 15 & 10 & 50 & 10 & 2 & 4 & & & 8 & 99 \\
\hline Wheat & 10 & 5 & 25 & 10 & & & & & 8 & 58 \\
\hline Jute & 10 & 25 & 10 & & & & & & 8 & 58 \\
\hline Potato & 20 & 10 & 50 & 20 & 5 & 6 & 5 & 3 & 13 & 132 \\
\hline Tomato & 20 & 16 & 30 & 30 & 3 & 6 & 5 & 2 & 16 & 127 \\
\hline Cabbage & 23 & 15 & 20 & 30 & 2 & 5 & 7 & 5 & 40 & 147 \\
\hline $\begin{array}{l}\text { Cauliflowe } \\
\mathrm{r}\end{array}$ & 20 & 30 & 20 & 18 & 3 & 5 & 6 & 4 & 20 & 126 \\
\hline Brinjal & 20 & 10 & 50 & 20 & 6 & 5 & & & 15 & 116 \\
\hline Chilly & 10 & 5 & 25 & 10 & 5 & & 6 & 2 & 13 & 76 \\
\hline Bean & 13 & 16 & 25 & 10 & 3 & 6 & 5 & 4 & 23 & 105 \\
\hline Carrot & 20 & 25 & 25 & 11 & 4 & 4 & & 1 & 23 & 113 \\
\hline Pea & 13 & 25 & 39 & 12 & 5 & 6 & & 3 & 20 & 123 \\
\hline Other Veg, & & & & & & & & & & \\
\hline
\end{tabular}

\section{Source: Field Survey,2010}

The Table NO.4, shows that the compound growth rates of all crops output and food grains output were higher in Assam than those of all other States. This indicated that the pace of agricultural development was much faster in Assam than in other parts of the country.

Table: 5

Role of Disseminating High Yielding Variety of Seed (HYV Seed) Among 200 Sample Farmers.

\begin{tabular}{|l|l|l|l|}
\hline \multirow{2}{*}{ Sl. No. } & \multirow{2}{*}{ Sources of Information } & \multicolumn{2}{|l|}{$\begin{array}{l}\text { No. of Farmers obtain information about HYV } \\
\text { Technology, N=200 }\end{array}$} \\
\cline { 3 - 4 } & & No. of Farmers & \% of Information recipients \\
\hline 1 & Village Level Extension Workers & 10 & 5.0 \\
\hline 2 & Radio & 16 & 8.0 \\
\hline 3 & Television & 4 & 2.0 \\
\hline 4 & Input Suppliers & & 52.5 \\
\hline 5 & Progressive Farmers & 105 & 30.0 \\
\hline 6 & News Paper & 60 & 1.5 \\
\hline 7 & Non-government organization (NGO's) & 2 & 1.0 \\
\hline 8 & Any Other Source (Brokers) & 0 & 100 \\
\hline Total & & 200 & \\
\hline
\end{tabular}

\section{Source: Field Survey, 2010}

It appears from table (5) that out of 200 sample farmers only 10 i.e. 5\% percent farmer is being provided with information of HYV seeds by the government employed village level extension workers. The role of ratio and television is also very negligible. Only 
16 i.e., $8 \%$ percent out of 200 respondents are found to have received information from radio and as low as 4 i.e., $2 \%$ percent) respondents were found to have received information of HYV seeds from television.

Table: 6

Role of Extension Personnel in Adopting Fertilizers among 200 Sample Farmers

\begin{tabular}{|l|l|l|l|}
\hline \multirow{2}{*}{ Sl. No. } & \multirow{2}{*}{ Sources of Information } & \multicolumn{2}{l|}{$\begin{array}{l}\text { No. of Farmers obtaining information about Fertilizers, } \\
\text { N=200 }\end{array}$} \\
\cline { 3 - 4 } & & No. of Farmers & \multicolumn{2}{l|}{$\%$ of Information recipients } \\
\hline 1 & Village Level Cultivators & 05 & $2.5 \%$ \\
\hline 2 & Radio & 21 & $10.5 \%$ \\
\hline 3 & Television & 01 & $.50 \%$ \\
\hline 4 & Input Suppliers & 64 & $32 \%$ \\
\hline 5 & Progressive Farmers & 37 & $37.5 \%$ \\
\hline 6 & News Paper & 02 & $1 \%$ \\
\hline 7 & Non-government organization (NGO's) & 12 & $6 \%$ \\
\hline 8 & At own initiative & 58 & $29 \%$ \\
\hline
\end{tabular}

\section{Source: Field Survey, 2010}

It appears from the table that it is input suppliers at whose initiative majority of the farmers are using fertilizer. As high as 64 i.e. about $32 \%$ percent farmers were found to had been receiving information about chemical fertilizers to be used in their Paddy field. Next to input suppliers it is progressive farmers that are playing important role in disseminating information about fertilizers. 37 sample farmers i.e., $17.5 \%$ percent were found to have gathered information about use of fertilizers to be used in Paddy fields as found during field investigations.

Table: 7

Fertilizer Consumption Figure in Different States (2001-02)

\begin{tabular}{|l|l|l|}
\hline Sl. No. & States & Fertilizer Consumption/ ha (in Kgs) \\
\hline 1 & Punjab & 173 \\
\hline 2 & Haryana & 155 \\
\hline 3 & Andhra Pradesh & 143 \\
\hline 4 & Tamil Nadu & 150 \\
\hline 5 & Uttar Pradesh & 125 \\
\hline 6 & Gujrat & 100 \\
\hline 7 & West Bengal & 100 \\
\hline
\end{tabular}




\begin{tabular}{|l|l|l|}
\hline 8 & Bihar & 90 \\
\hline 9 & Karnataka & 70 \\
\hline 10 & Maharastra & 60 \\
\hline 11 & Madhya Pradesh & 50 \\
\hline 12 & Rajasthan & 45 \\
\hline 13 & Orissa & 40 \\
\hline 14 & Assam & 20 \\
\hline
\end{tabular}

\section{Source: Economic Survey, 2007-08}

The Table. NO. (7) depicts that among major Indian states the fertilizer consumption is the highest in Punjab and lowest in Assam $(20 \mathrm{Kg} / \mathrm{ha}$ ).It appears from Secondary data furnished by Directorate of Agriculture, Assam that consumption of fertilizers is not uniform among various districts of Assam. It also appears that Darrang district also in some other districts the consumption of fertilizer has been very low. The following table shows the fertilizer consumption figure in different districts in Assam in the year 2008-10.

Table: 8

District-wise Consumption of Fertilizer in Assam, During the Year 2008-10

\begin{tabular}{|c|c|c|c|c|}
\hline $\begin{array}{l}\text { Sl. } \\
\text { No. }\end{array}$ & District & $\begin{array}{l}\text { Total cropped area (in } \\
\text { Ha) }\end{array}$ & $\begin{array}{l}\text { Total fertilizer } \\
\text { used(ing./ha) } \mathrm{N}+\mathrm{P}+\mathrm{K}\end{array}$ & $\begin{array}{l}\text { Fertilizer used } \\
\text { p/h(in Kgs) }\end{array}$ \\
\hline 1. & Dhubri & 227000 & 3920000 & 17.26 \\
\hline 2. & Kokrajhar & 143000 & 1607000 & 11.23 \\
\hline 3. & Goalpara & 98000 & 2703000 & 27.58 \\
\hline 4. & Bongaigaon & 153000 & 4038000 & 26.39 \\
\hline 5. & Barpeta & 313000 & 4425000 & 14.13 \\
\hline 6. & Nalbari & 197000 & 4723000 & 23.97 \\
\hline 7. & Kamrup & 223000 & 7063000 & 31.67 \\
\hline 8. & Darrang & 479000 & 5637000 & 11.76 \\
\hline 9. & Sonitpur & 223000 & 1965000 & 8.81 \\
\hline 10. & Lakhimpur & 157000 & 512000 & 3.26 \\
\hline 11. & Dhemaji & 90000 & 109000 & 1.21 \\
\hline 12. & Marigaon & 126000 & 946000 & 9.50 \\
\hline 13. & Naogaon & 381000 & 12492000 & 32.78 \\
\hline 14. & Golaghat & 175000 & 1979000 & 11.30 \\
\hline 15. & Jorhat & 164000 & 2414000 & 14.71 \\
\hline 16. & Sibsagar & 164000 & 1808000 & 11.02 \\
\hline 17. & Dibrugarh & 16000 & 3891000 & 24.31 \\
\hline
\end{tabular}




\begin{tabular}{|l|l|l|l|l|}
\hline 18. & Tinsukia & 128000 & 447300 & 34.94 \\
\hline 19. & K.Anglong & 181000 & 197000 & 1.08 \\
\hline 20. & N.C. Hills & 35000 & 20000 & 0.57 \\
\hline 21. & Karimganj & 108000 & 681000 & 6.30 \\
\hline 22. & Hailakandi & 60000 & 1524000 & 25.4 \\
\hline 23. & Cachar & 139000 & 2460000 & 17.69 \\
\hline & Assam & 3926000 & 78102000 & 19.89 \\
\hline
\end{tabular}

Source: Directorate of Agriculture, Assam; Statistical Hand Book, Assam, 2008, 2010.

Scanning of the table shows that per hectare consumption of fertilizer in Assam is only $20 \mathrm{~kg}$, which is much less than all India consumption figures of $90 \mathrm{~kg}$. As regards the consumption figure of Darrang district, it is only $14.13 \mathrm{~kg} / \mathrm{ha}$ which is lower than the state figure of $20 \mathrm{~kg} / \mathrm{ha}$. Among the districts of Assam, it is KarbiAnglong and North Cachar Hills using the lowest quantity of fertilizer respectively. It can be concluded that due to ineffective and insufficient extension services the adoption of fertilizers has been very low in Darrang district as well as in other districts in Assam.

Table: 9

Showing Table Role of Extension Personnel in Adopting Pesticides

\begin{tabular}{|l|l|l|l|}
\hline \multirow{2}{*}{ S1. No. } & \multirow{2}{*}{ Sources of Information } & \multicolumn{2}{|l|}{$\begin{array}{l}\text { No. of Farmers obtaining information about use of } \\
\text { Pesticide, N=200 }\end{array}$} \\
\cline { 3 - 4 } & & $\begin{array}{l}\text { No. of sample farmers } \\
\text { obtaining information about } \\
\text { pesticides }\end{array}$ & $\begin{array}{l}\text { \% of Information } \\
\text { recipients }\end{array}$ \\
\hline 1 & Village Level Worker & 0 & 0 \\
\hline 2 & Radio & 13 & 6.50 \\
\hline 3 & Television & O2 & 1 \\
\hline 4 & Input Suppliers & 39 & 19.50 \\
\hline 5 & Progressive Farmers & 73 & 36.50 \\
\hline 6 & News Paper & 01 & 0.50 \\
\hline 7 & (NGO's) & 35 & 17.520 \\
\hline 8 & Others & 37 & 18.50 \\
\hline
\end{tabular}

\section{Source: Field Survey, 2010}

An examination of Table (9) reveals that out of 200 sample respondents not single respondents received information from farmers about the use of Pesticide as means of plant Protection measure. It is again input suppliers who are playing important role in providing information about pesticide use. During field survey 13 i.e. 6.5 percent sample farmers were found adopted Pesticides as means of plant protection measures at the initiative of input suppliers. Next to input suppliers it was progressive farmers who were playing significant role in dissemination information about pesticide among the farmers. As high as 02 i.e 0.10 percent sample farmers reported adopting pesticide following the suggestion of nearby progressive farmers. Another important feature that appears from the table is that recently some NGO's in some areas are helping farmers providing message of modern agricultural practices. During field investigation 35 i.e., 
17.50 percent sample farmers reported adopting pesticide at the initiative of some members of some NGO's. It is to be noted that some members of NGO's reported of being trained by district agricultural officers in matter of use of agricultural inputs.

Table: 10

Role of Extension Personnel in Providing Information about Irrigation Facilities

\begin{tabular}{|l|l|l|l|}
\hline $\begin{array}{l}\text { Sl. } \\
\text { No. }\end{array}$ & Sources of Information & $\begin{array}{l}\text { No. of Farmers obtaining } \\
\text { information about irrigation } \\
\text { N=200 }\end{array}$ & $\begin{array}{l}\text { Percentage of } \\
\text { information } \\
\text { recipients }\end{array}$ \\
\hline 1 & V.L.E.W & 0 & 0 \\
\hline 2 & Radio & 04 & 2 \\
\hline 3 & Television & 6 & 3 \\
\hline 4 & Input suppliers & 0 & 0 \\
\hline 5 & Progressive farmers & 17 & 1 \\
\hline 6 & Newspaper & 01 & 1 \\
\hline 7 & Non-Govt. org. & 20 & 5 \\
\hline 8 & Other, (Traders \& Brokers) & 16 & 8 \\
\hline
\end{tabular}

\section{Source: Field Survey, 2010}

From scanning the table it appears that out of 200 sample farmer's not single farmer reported obtaining information about irrigation facility from village level extension workers and Television. Only 6 sample farmers reported to have obtained information about irrigation facility from radio and newspaper each. It also appears from the table that 10 sample farmers reported to have obtained information of irrigation facility from input suppliers and Progressive farmer each.

Table: 11

Role of Extension Service in relation to the Adoption of Modern Agricultural Implements

\begin{tabular}{|l|l|lr|l|}
\hline $\begin{array}{l}\text { S1. } \\
\text { No. }\end{array}$ & $\begin{array}{l}\text { Sources } \\
\text { of Information }\end{array}$ & $\begin{array}{l}\text { No. of Farmers obtaining } \\
\text { information about Agricultural } \\
\text { Implements } \\
\mathrm{N}=200\end{array}$ & $\begin{array}{l}\text { Percentage of } \\
\text { information } \\
\text { Recipients }\end{array}$ \\
\hline 1 & Village level & 10 & 5.00 \\
\hline 2 & Radio & 07 & 3.50 \\
\hline 3 & Television & 04 & 2.50 \\
\hline 4 & Input suppliers & 88 & 44.00 \\
\hline 5 & Progressive Farmers & 16 & 8.00 \\
\hline 6 & Newspapers & 07 & 3.50 \\
\hline 7 & NGO's & 04 & 2.00 \\
\hline 8 & Others & 11 & 5.50 \\
\hline
\end{tabular}




\begin{tabular}{|l|l|l|}
\hline Total & 147 & 69.50 \\
\hline
\end{tabular}

\section{Source: Field Survey, 2010}

Scanning of the table shows that altogether 147 i.e., 69.50 percent farmers reported about obtaining information about agricultural implements from various sources. Only 10 i.e., 4 percent sample farmers obtained information about agricultural implements from village level extension workers. The role of radio and television is also not encouraging. It appears from table that as low as 4 and 4 farmers reported to have obtained information about agricultural implement from radio and television respectively.

Table NO. 12

\begin{tabular}{|l|l|l|l|}
\hline $\begin{array}{l}\text { Sl. } \\
\text { No. }\end{array}$ & $\begin{array}{l}\text { Sources } \\
\text { of Information }\end{array}$ & $\begin{array}{l}\text { No. of Farmers obtaining } \\
\text { information about Institutional } \\
\text { credit } \\
\text { N=200 }\end{array}$ & $\begin{array}{l}\text { Percentage of } \\
\text { information } \\
\text { Recipients }\end{array}$ \\
\hline 1 & Village level & 0 & 0 \\
\hline 2 & Radio & 0 & 0 \\
\hline 3 & Television & 0 & 0 \\
\hline 4 & Input suppliers & 0 & 0 \\
\hline 5 & Progressive Farmers & 56 & 28.00 \\
\hline 6 & Newspapers & 11 & 5.50 \\
\hline 7 & NGO's & 35 & 17.50 \\
\hline 8 & Brokers/ middlemen & 98 & 49.00 \\
\hline Total & 200 & 100 \\
\hline
\end{tabular}

\section{Source: Field Survey, 2010}

It appears from the table that role of village level extension personnel, Radio and Television was found nil in dissemination of information about institutional credit during field survey. It is brokers who play significant role in obtaining bank agricultural loan by the farmers. Some young unemployed youths were found involved in providing information and obtaining loan as well. In return they take certain percentage of the loan obtained so far as was stated by some sample farmers during field survey.

Table: 13

Change in Agricultural Productivity as Dependent Variable with Darrang District. ( $\mathrm{N}=\mathbf{2 0 0})$

\begin{tabular}{|lccc|}
\hline Agro-Ecological Part & Constant & Standard Error & Coefficient \\
\hline West Darrang & 2652.70 & 213.76 & 0.980 \\
& & & \\
\hline East Darrang & 353.63 & 151.86 & 0.869 \\
& & & \\
\hline North Darrang & 523.69 & 154.57 & 0.362 \\
& & & \\
\hline South Darrang & 2102.82 & 305.72 & 0.421 \\
& & & \\
\hline
\end{tabular}

Source: Agriculture Office, Darang District in Assam.

Production factors analysis shows table no. 13, it indicates that the expansion in the area under HYVs has a significantly positive effect on increasing agricultural productivity specially in the areas of most flood -prone and humid conditions in the west and south part of the Darrang district where resistant summer Paddy HYVs (High Yielding Variety) like Sali paddy, Boro, IR-9 and Ahu paddy varieties are locally developed and popular among the peasants of Assam. 


\section{FINDINGS OF ThE PRESENT STUDY :}

The present investigator derived a number of hypotheses. On the basis of analysis, interpretation of data and discussion of results, the hypotheses were tested and verified. The major findings of the present investigation the respective hypotheses were treated and the following finding and conclusions were arrived. Major finding and conclusions emerged out of the data obtained empirically in the present study as follows:

(1) The present investigation revealed that the farmers retained the practice of using improved varieties. In the production process they utilized their scarce land in much better way so as to achieve higher gain. This might have increased the efficiency of land and improved the cropping pattern and crop rotation. An increase in the area under cash crops indicated a hike in their tendency towards commercial farming and maximization of net return. The results also revealed that irrigation was the single cardinal factor for transforming the traditional farm-behaviour to a modernized one.

(2) The programme has significant positive impact on gross cropped area, cropping intensity and productivity. Better cropping pattern reflected from the increase in area under HYVs of paddy and cash crops enhanced the average cropped area for PG farmers. This resulted in the increase in average cropping intensity. More intensive cultivation led to an increase in yield and productivity.

(3) Profit per acre of land was observed to be higher for the target group after ' 84 while it was almost same before' 82 in comparison to NPG. This indicates that Programme had some impact on gross profit. The amount of average gross profit, increased, could be utilized for home consumption or channelized in the market. Under Technology Mission for Development of Integrated Horticulture in Assam, the amount received for the structure Mini Mission -II during 2001-2002 and 2002-2003 were Rs. 610.12 lakh and Rs. 1092.40 lakh respectively. Likewise the amount received for the structure Mini Mission III during 20012002 and 2002-2003 were Rs. 17.04 lakh and Rs. 143.75 lakh respectively.

(4) Some very interesting results were obtained from the analysis of distributive effects of the programme. It was observed that the income distributions for PG farmers were skewed towards the low income group in both before ' 82 as well as after 84 '. Major portion of income was concentrated to the poorest farmers within the group of small and marginal farmers. Even within a group of small and marginal farmers the well-off farmers achieving more income by way of better adoption than the worse-off farmers. This result amply suggested that to implements a TOT how difficult was to maintain the welfare objective. The result further suggests that the advocated technology was not at scale neutral.

(5) Farm size and percentage of cash crops in total crop were found to be the most important characters associated with adoption behaviour. Owners of relatively big farms, who could be thought as well as-off farmers in the group, were in a position to adopt the technology because of their relatively higher access to wealth. This indicated the moderate impact of the programme on adoption. Since the LLP had failed to raise the farmers to good adopters it could be justified to conclude that the adoption effect of the programme was mediate. Through the moderate adoption of advocated technologies farmers were able to raise the productivity of crops and thereby obtained higher gains in the form of gross profit.

(6) A set of twenty constraints, as perceived by PG and NPG farmers, were identified in course of this study. Regarding the presence of constraints at the farm level, both the PG and NPG farmers perceived in similar pattern. These constraints were categories into (i) environmental, (ii) agro-biological and (iii) Socio-economic of these, agro-biological constituted the maximum in the set followed by the socio-economic and environmental

They present author had developed a Paradigm on the basis of certain assumptions and certain hypotheses. Major components of the have been clearly depicted in the presentation, interpretation of results and dependence on certain aspects and other related matters for creating a definite impact in the present study.

\section{CONCLUSIONS In The PRESENT StUdy:}

On the basis of analysis, interpretation of data and discussion the results, the hypotheses were tested and verified. Some of them were retained and some other was rejected. The major findings of the present investigation the respective hypotheses were tested and the following conclusions were arrived. Major conclusions emerged out of the data obtained empirically in the present study of the investigation may be drawn as follows:

in conclusion, higher investment in farm operations are related rural infrastructure is a necessary condition for speedier farm growth. Accelerating the pace of capital formation under public sector ensuring remunerative price for agricultural produce, infrastructure development will enable the rural sector to adopt more modern technology in agriculture and Government Department have to work in a coordinating manner to address the above issues for ensuring greater benefits from this sector. Most of the farmers are increasingly adopting new technology in agriculture. Dissemination of agricultural technology largely depends on effective and timely changing activities of Vegetables Extension. But field study shows that village level extension personnel are playing very insignificant role disseminating new agricultural technology among the farmers of Darrang District. Out of 200 farmers.

The present study shows that mainly small and marginal farmers depend upon progressive and large farmers for adoption of modern agricultural technology. These dependent farmers are basically late adopters of modern agricultural technology in comparison to progressive farmers and hence not in a position to reap the early benefits of modern technology.It is observed that there has been a gradual decline in the area coverage under Autumn Rice in the Date in recent years. During 2002-2003. This is due to diversion of area under autumn Rice to the area under other crops during the year. Area under winter Rice, the principal. Kharifcrop increased marginally to 17.49 lakh hectares in 20022003 from 17.15 lakh hectares in 2001-2002.

The study also shows that, recently, some nongovernmental organization (NGO's) are found getting involved in disseminating exercise of modern agricultural technologies. But their involvement is at embryonic stage and their working field is found to be continued only in some limited areas.Some brokers 
and middlemen have been found to be involved in helping farmers getting institutionalized credit. But most of the loanee farmers reported that brokers or middlemen charge commission in return of their help. As many as 200 sample farmers reported that brokers charged commission in return.

Assistance: During field survey, many sample farmers reported that brokers charge as high as 20 to 25 percent of their raised agricultural loan. These malpractices could have been done away with if village level extension workers would have been involved in percolating information about agricultural loan. But field investigation shows that not a single sample farmer has been helped by VLEW in raising institutional credit.

Majority of the farmers are adopting modern agricultural technology at the initiative of input suppliers. Basically, it is input suppliers who are providing the maximum extension services among the farmers in relation to agricultural technology. But field study shows that most of the input suppliers are neither knowledgeable nor properly educated for agricultural technology dissemination purpose. They do it mainly keeping in view their business interest.

It is evident from the field study that non-formal extension services i.e. mainly input suppliers and progressive farmers are playing a major role in disseminating the agricultural technology related information. So farmers are basically dependent on nonformal source rather than public extension system for getting advice as well as farming inputs which appeared to us really astonishing and unbelievable. During our field investigation many farmers reported that they had not even heard the name of agricultural extension personnel; not to speak of being met them.

\section{SugGeStions:}

As the major focus of the present investigation is on the exploration of the study,' Adoption of New Technology \& Vegetable Cultivation in Darrang District of Assam', and its findings and limitation of the present study, following suggestions are given to conduct the further research in the field of agriculture. Finally, for having an idea on the most crucial variable associated with the adoption behaviour of clients, 'farm- size' was depicted in the paradigm. In relation to practical utility these are of much academic value and interesting in nature. Hence, these deserve immediate and adequate attention of the policymakers, planners, administrators, social scientists, economists, economists and other interested in meaningful dissemination of technology for agricultural and rural development.

\section{REFERENCES}

[1] Alagh,Y.K. (1979). Indian planning in the eighties. Economic and Political Weekly. XIV (30,31 and 32). Special number.

[2] Alagh, Y.K. and Sharma, P.S. (1980). Growth of crop production: 1960-61 to 1978-79- is it decelerating ? Indian Journal of Agricultural Economics.

[3] Arul Raj, S and Knight, A.J. (1977). Influence of farm-practice-attributes on innovation-decision process. Indian Journal of Extension Education.

[4] Bagchee, S.(1987). Poverty alleviation programmes in Seventh Plan: an apprisal. Economic and Political Weekly. XXXII (4).

[5] Bahadur, T. etal (1980), Impact of DPAP on farm income and resource productivity; an emperical study of farming of weaker section. Indian Journal of Agricultural Economics.

[6] Banarjee, B and Dutta Roy, S (1987). Economics of small and large farms in Haringhata block of Nadia district, West Bengal: a case study. Economic Affairs.

[7] Bardhan, P.K.(1974). Inequality of farm incomes: a study on four districts. Economic and Political Weekly. IX $(6,7,8)$

[8] http://www.saarcnet.com/newsaarcnet/govtpolicies

[9] http://pib.nic.in/archieve/lreleng

[10] http://commerce.nic.in/nepal.doc

[11] http://www.catmando.com/gov/industry/fipd

[12] http://www.saarcnet.org/newsaarcnet/saarclinks/publications

[13] http://www.facd.gov.np/news

[14] http://www.nepalnews.com.np/contents/englishdaily/ktmpost

[15] http://www.ncti-india.com/htdocs/aboutus.htm

\section{AUTHORS}

First Author - Dr. Mizanur Rahman, Associate. Prof. Dept. of Economics, Kharupetia College, Darrang, Assam. 